\title{
THE EUROPEAN UNION MARKET FROM THE ASPECT OF THE COMPETITION AND BASIC VALUES OF ROMAN LAW
}

\begin{abstract}
The rich treasury of Roman law requires a continuous scientific research. The values of Roman law in the process of globalization are achieving the notable results in the creation of a new ius commune. Today, the logistical aspect of the European legal systems takes place in the domain of Roman law, and some of its values are recognizable in the course of economic life on the market within the encounter of the national and $\mathrm{Eu}-$ ropean Union Law. The methodological and institutionalized framework of the competition law is used to achieve positive effects in the single market, paving the way for the even distribution of social wealth. The market cannot neutralize the behavior of business entities using the competition to achieve extra profits. So, detecting and placing all possible forms of embezzlement used by business entities under the legal framework is a difficult task dealt with by competition policy entities, largely using the legal institutes of Roman law.
\end{abstract}

Keywords: Roman law, competition law, bona fides, The European single market

\section{Introduction}

Certain characteristics of the Single Market regularly raise doubts of a legal nature, in which issues come to the fore the lasting value of Roman law, as a spontaneous consequence of maintaining the intangible world of

\footnotetext{
* PhD, assistant professor, The University of Business Academy in Novi Sad, Serbia, The Faculty of European Legal and Political Studies, Novi Sad, Serbia, e-mail: mstojkovic1@yahoo.com
} 
the knowledge market. De lege lata, Court of Justice of the European Union, when resolving cases where there is no clearly defined rule of Community law, base their decisions on the dictumes of the Roman ius commune.

There is an interesting parallel between the medieval and modern European ius commune. Roman rules and the principle of bona fides are one of the most impressive values of Roman law. Current research related to Roman law not only supports the process of globalization, but is the main actors of harmonization and unification as legal processes crucial for the legality and legitimacy of the existence of the European Union as a specific international legal entity.

\section{The legal power of Latin sentences}

Within the work of Court of Justice of the European Union, we notice that the use of old maxims in Latin is frequent. Increasingly, there is a revival of Roman legal institutes in the process of harmonization of rights and legal systems, and the use of maxims and sentences by the competent authorities and institutions is present in order to enrich legal expression. The focus is on the rhetorical sense, as well as on the improvement of nomotechnics. Bene docet, qui bene distinguit. ${ }^{1}$

De facto, latin legal rules have led to greater agreement in the handling of cases in legal matters than national law regulations, which is the greatest satisfaction of timeless values. A prima facie, generally accepted legal principles of the European Union are applied in the case of legal gaps, and are recognized in the form of old Latin sentences. Bonus iudex secundum aequum et bonum iudicat, et aequitatem stricto iuri praefert. ${ }^{2}$

Unfortunately, today in the legal world there are many beliefs to force the principle of not having the right to make a mistake, where strictly following the formal procedure, one often moves away from the essence of legal matters, and thus from justice and fairness, as the mother of all legal systems. But, as Seneca said, et post malam segetem serendum est. ${ }^{3}$ Accordingly, researchers of modern Roman law bear a great responsibility to protect the richest treasury of legal civilization.

\footnotetext{
${ }^{1}$ He teaches well when he distinguishes (things) well.

${ }^{2}$ A good judge judges right and well and prefers fairness over strict application of law. Petrušić, N., Adamović, A. (2012). Latinske izreke, pravila i izrazi iz oblasti civilne procedure, [Latin sentences, rules and expressions in the field of civil procedure]. Niš, Centar za publikacije Pravnog fakulteta u Nišu, p. 12.

${ }^{3}$ And after a poor harvest should be sown.
} 
Nikolic says that of the numerous works of classical jurists, only three have been preserved in their entirety: "The institutes of Gaius", Ulpian's "Regulations" and Paulus's "Sentences". ${ }^{4}$ It should be noted that Justinian's codification is of central importance, because it represents Roman law composed and systematized within the monumental legal collection- Corpus Iuris Civilis. $^{5}$

\section{Roman concept}

Eo ipso, bona fides is tied to the notion of the principles of conscientiousness and honesty. The Roman concept was accepted by medieval jurists. Through the review of Roman law, it was implemented in obligatory relations, in accordance with the postulate ex aequo et bono ${ }^{6}$. Literally translated, it means good faith. Today, when the focus is on the mere execution of the law, the central idea of the Romans, which has a focus on lasting values, is missing. In particular, the term fides means fidelity to a given word, while bona fides confirms the content of the contract, and essentially implies respect for conscientiousness, morals and good customs.

Faithfulness to one's own word is a prerequisite for any contractual relationship and therefore Cicero defines it as fundamentum iustitiae. ${ }^{7}$ The field of the most significant action bona fides are bonae fidei informal contracts. In the modern world, the question arises as to whether the attempt to achieve perfectionism in legal transactions serves the basic purpose of contractual obligations, since in the past minor detours of the truth were not a particular problem for either party. ${ }^{8}$

It is an everyday occurrence that there is an obvious disproportion between reciprocal benefits on the European market, while Thomas Aquinas derived the definition of the legal rule that it is more expensive to sell and cheaper to buy a thing than what it is worth - unfair and impermissible. ${ }^{9}$

\footnotetext{
${ }^{4}$ Nikolić, D. (2007). Opšta istorija prava [General history of law]. Niš, SVEN, p. 127.

${ }^{5}$ The most significant and extensive part of the codification is the Digesta, the content of which consists mainly of quotations from classical jurists.

${ }^{6}$ At the request of justice and honesty.

${ }^{7}$ Fundamentum autem est iustitiae fides, id est dictorum conventorumque constantia et veritas. Miller, W. (1913). M. Tullius Cicero. De Officiis., Cambridge, Harvard University Press, Cambridge, Mass., London, England., art.1.23.

${ }^{8}$ Stanojević, O. (2003). Rimsko pravo, [Roman Law]. Beograd, p. 370.

${ }^{9}$ Iustitia est constants et perpetua voluntas ius suum cuique tribuendi. Akvinski, T. (1985). Izabrano djelo, [Selected work]. Zagreb, p. 19.
} 


\section{The European Union single market}

The European Union has done much for modern business conditions in the single market by improving the legal framework for certain sectors such as financial services, energy, telecommunications and postal services, the pharmaceutical industry, the smartphone and e-shopping market, the music industry and transport. Numerous regulations have been passed in the function of more efficient work and easier identification of irregularities through new tools for gathering information on the European Union market, and a mechanism for indirect transmission of wealth from strong to weak sectors has been created.

This traditional role of competition policy is realized in two ways, one of which is to stimulate the construction of a strong internal market of this union, and the other to harmonize market laws with the laws of industrial policy. The most important means of competition policy in promoting the single market are anti-cartel policy, enforcement of merger regulation and control of state aid policy, in accordance with the Roman law institute bona fides.

The process of creating competition policy in the single market of the European Union implies a kind of neutrality and resistance of competition policy makers to political and corrupt pressures. The key elements of this market include factors influencing the formation and implementation of this type of policy, such as consumer welfare, consumer protection, wealth redistribution, protection of small and medium enterprises, regional, social and industrial aspects, as well as market integration.

\section{Cartelization}

Secret agreements between market participants, which are established with the aim of agreeing on a single price, market sharing, consumer sharing, territorial allocation of products and services, setting the offer, promoting their own sales agencies, and creating extra profits for each company within the cartel, are not uncommon for today's business entities. Through private and public cartels, there is no possibility for consumers to exercise the right to free choice, while economic entities within the cartel thus realize extra profit. Detecting a cartel is a complicated process, even for the European Commission.

Public cartels usually involve a government that guarantees a given cartel, and they are most often established in industries that are in their 
infancy or in the rationalization of their structures, bringing benefits to society as a whole. In contrast, the Commission bans private cartels that make extra profits up to $25 \%$ of regular profits. ${ }^{10}$ European Union Law prohibits agreements that may affect trade between Member States in the market by significantly distorting, preventing and restricting competition. ${ }^{11}$

There are cases when these types of connections "contribute to companies eliminating competition through these agreements, decisions or concentrations because they participate in the improvement or progress", ${ }^{12}$ and then there are justified exceptions. A case that can be qualified as an exception must meet the following cumulative conditions: the agreement must contribute to the European Union market as a whole and prove that the advantages of its existence are far more important than possible disadvantages, that it distributes benefits to all consumers and customers that we cannot significantly eliminate competition.

\section{Concentrations and unilateral behavior of economic entities}

The realization of concentrations, under certain conditions, may represent a desirable market situation because concentrations represent a legal form of business consolidation of economic entities. The goal of concentration control is reflected in the assessment of the degree of competitiveness, as well as the effects of the observed market on consumer interests and social welfare. The practice of concentration in terms of merging companies in order to achieve common goals is a form of cooperation between companies, especially in the oligopolistic market. It is interesting that the exclusive distribution agreement, without abusing its dominant position, can affect trade between member states. ${ }^{13}$

\footnotetext{
${ }^{10}$ Marković-Bajalović, D. (2000). Tržišna moć preduzeća i antimonopolsko pravo, [Company market power and antitrust law]. Beograd, Službeni list SRJ, p. 78.

${ }^{11}$ The ban also applies to the creation of concentrations by market competition actors through the decisions and actions of business entities in the role of creators of these specific formations.

${ }^{12}$ Cini, M., McGowan, L. (2008). Competition Policy in the European Union, 2nd edition, Basingstoke, Palgrave Macmillan, p. 60.

${ }^{13}$ One of the cases in practice where the Commission had one of its analyzes to distinguish the criteria of good from bad associations, is the business of a Dutch business entity, Van Megen Sports, as a company based in Eidhoven, was the exclusive distributor of tennis balls of the Swedish company Tretorn for the Dutch market, which tried to distribute balls in packages in this territory at lower prices, while at the same time placing its exports at parallel prices. Tennis balls were sold at different prices in different countries depending on the distributor, and there were no codes on the invoices to determine where the shipments were sent from.
} 
Market cartelization does not necessarily involve the participation of two or more companies, but the company can, by its unilateral behavior, cause effects on competition similar to those produced by some kind of agreement. If the conduct of certain business entities affects trade between Member States, the Commission will react through its powers. The courts of the Member States must not be inconsistent with competition policy and law. The operation of the Commission's competition law is applicable only in the territory of the Member States, which emphasizes the territorial principle. However, the application of competition law may also apply to practices outside the territory of the European Union if it or its subsidiary affects competition within the European Union market.

\section{The Roman institutes and practice in the single market}

In one of its decisions, the Commission found that the undertakings Akzo Nobel, Akzo Chemicals Holding and Eka Chemicals had participated in an infringement of Article 81 EEC, in the territory of the European Union, with fourteen other companies participating in the hydrogen peroxide and perborate sector. Therefore, they were jointly and severally fined 25.2 million euros. ${ }^{14}$

An injured party in a contract that is capable of restricting or distorting competition may invoke an infringement of competition law in order to obtain damages from the other party. The full effectiveness of Article 85 of the Treaty, and in particular, the practical effect of the prohibition in Article 85 , paragraph 1 , would be jeopardized if any individual could not claim compensation for damage caused by contract or conduct capable of restricting or endangering competition. ${ }^{15}$ The Roman legal rule that it is more expensive to sell and buy a thing cheaper than what it is worth - unjustly and impermissibly, is expressed precisely in this legal matter in the spirit of the modern principle of equivalence of the law of obligations.

The existence of a right to compensation strengthens the effect of competition rules and discourages the conclusion of agreements and practices, which are often secret and which could restrict or distort competition. European Union Law excludes the application of the rules of national law according

\footnotetext{
${ }^{14}$ Judgment of the Court of Justice, in case T-345/12 Akzo Nobel et al. against the Commission, dated 28 January 2015.

${ }^{15}$ Judgment of the Court of Justice in the case C-453/99, Courage Ltd v. Bernard Crehan and Bernard Crehan v. Courage Ltd et al.
} 
to which one of the parties to the contract is prohibited from claiming damages caused by the performance of that contract. For example, "the European Union competition law regime does not allow the abuse of rights existing under national trademark laws to diminish the effectiveness of anti-cartel law." ${ }^{16}$

Judicial review of the Commission's complex assessments in the matter of exemptions from the prohibition of cartels must take into account the nature of those assessments and be limited to examining the importance of the facts and the legal consequences which the Commission derives from them. This verification must be carried out in the first place with regard to the reasoning of the decisions in which the facts and reasons underlying the assessment are to be specified.

The improvement in the production or distribution of products that is necessary for the application of the exemption cannot be identified with all the advantages that the contracting parties to the agreement gain in their production, ie, distribution activities. The content of the notion of "improvement" should not depend on the specific features of specific contractual relationships. This improvement must in particular demonstrate tangible objective advantages which are of such a nature as to be able to compensate for any shortcomings caused in the field of competition by specific acts or omissions.

In its assessment of the relative importance of the various factors put to it for examination, the Commission should both assess their effectiveness in relation to improving the production and distribution of objectively identifiable products and decide whether the benefits of the improvements would be sufficient to the accompanying restrictions of competition are considered necessary, again with the emphasized necessity to bring a specific legal matter under the Roman law institute bona fides, and to bring the economic life of the Single Market under the framework of honorable, fair and done in good faith.

The European Union is characterized by a single market under a system of laws applicable in all Member States, which guarantees the free movement of people, goods, services and capital. Therefore, it is logical to focus on man and his legal position, and not on the formal and procedural understanding of contractual relations, all in accordance with the principle of conscientiousness and honesty, as a basic values of Roman law.

Experientia docet, in this regard, the French Civil Code adopts the principle of conscientiousness and honesty, based on centuries of developed

\footnotetext{
${ }^{16}$ Judgment of the ECJ in Joined Cases 56 and 58/64, Consten and Grunding v. EC Commission, 13 July 1966.
} 
bona fides, and the treaties bind not only what is stated in them, but also everything that justice, custom or law by their nature binds. ${ }^{17}$

Then, in a specific legal matter, the Court of Justice of the European Union ordered Euroatom to compensate the plaintiff on the basis of the conclusion of the general rule alterum non laedere. All European legal systems are familiar with this rule expressed in the above-mentioned Latin sentence, which in a specific legal matter has resulted in the obligation of the European Union to remedy the damage in accordance with generally accepted legal principles at the national levels of the Member States. ${ }^{18}$

Among the pleas in law in the proceedings before the Court of Justice of the European Union, such as the plea alleging lack of legal basis for the contested decision, the Commission's failure to authorize ratione temporis and the breach of essential procedural requirements, the principles of breach of legal certainty and protection of legitimate expectations, is a violation of the principle of ne bis in idem and the principle of proportionality. ${ }^{19}$

$\mathrm{Ne}$ bis in idem is a principled prohibition of retrial arising from the interests of legal certainty and fairness, and in the modern world it includes an analysis of close connection in terms of content and time, in order to achieve a clear insight into the issues of a specific legal matter. In analyzing the principle of proportionality as a value of Roman law in the case law, we approach it through the Billerud case. In conducting its proportionality analysis, the Court uses different standards of examination, depending on the subject matter, for the discretionary choice of policy, penalty and fundamental rights.

Namely, the Swedish environmental protection agency, imposed penalties on the Billerud companies for failing to surrender credits under the EU Emissions Trading Scheme in 2006. The Billerud companies challenged the penalties arguing that since the failure was due to an internal error and the companies had a sufficient number of allowances at the time, they should be excused. The Court of Justice of the European Union found that under Directive 2003/87/EZ, penalties for failure to surrender credits still apply even if the entity held a sufficient number of allowances at that time. In addition,

\footnotetext{
${ }^{17}$ Fondation Napoléon (2020, September 15). Code civil des français, [Civil Code of the French]. Downloaded from: https:/www.assemblee-nationale.fr/evenements/code-civil-1804-1.asp art. 1135.

${ }^{18}$ Judgment of the Court (Sixth Chamber) of 3 February 1994, Alfredo Grifoni v European Atomic Energy Community, Non-contractual liability - Compensation for loss, Case C-308/87, ECLI:EU:C:1994:38.

${ }^{19}$ Judgment of the Court of 27 February 2019, Greece v Commission, European Agricultural Guidance and Guarantee Fund (EAGGF), C-670/17 P, ECLI:EU:C:2019:145.
} 
the CJEU found that the penalty was a lump sum and may not be varied by a national court on the basis of the principle of proportionality. ${ }^{20}$

\section{Instead of a conclusion}

In anti-cartel law, there is a boundary between the scope of European Union Law and national law. It is important to know whether a particular behavior is capable of presenting, directly or indirectly, a real or potential threat to freedom of trade between Member States in such a way as to jeopardize the realization of the objectives of the single market between States. Latin legal rules lead to greater agreement in the handling of cases in legal matters than the regulations of national law, which is the greatest satisfaction for modern researchers of Roman law.

Imperfect competition is regulated by competition policy through legislative forms. The legal framework of competition prevents anticompetitive behavior of market players who in the race for permanent extra profit turn the market into a predictable category. Its preventive action prevents the maneuvers of large companies, which by their actions on the market create confusion among other actors. The aspiration in resolving specific legal matters is to bring every decision under the Roman law institute bona fides, in order to bring the economic life of the Single Market under the framework of honorable, honest and done in good faith. As a guarantee of the free movement of people, goods, services and capital, the basic values of Roman law focus on man and his legal position.

All European legal systems know the rule of alterum non laedere in accordance with the generally accepted Roman law institutes of equality and justice, conscientiousness and honesty (ex aequo et bono). Also, in practice, we often encounter violations of the principle of ne bis in idem, as well as the principle of proportionality, as an institute of Roman law that are unavoidable in the legal life of the European Union and its Single Market.

Detecting and placing under the legislative framework all possible forms of embezzlement used by business entities is a difficult task, but not impossible, especially with reliance on the enduring values of Roman law, as a very important tool in all legal spheres, both formal and procedural, all in the spirit of the values of Roman law which in the process of globalization have had notable results in the creation of a new ius commune.

\footnotetext{
${ }^{20}$ Billerud Karlsborg AB v. Swedish Environmental Protection Agency, "Billerud Karlsborg AB v. Naturvardsverket", Case C-203/12.
} 


\title{
Stojković Milica
}

Doc. dr, Fakultet za evropske pravno-političke studije, Univerzitet Privredna akademija u Novom Sadu, Srbija

\section{TRŽIŠTE EVROPSKE UNIJE SA ASPEKTA KONKURENCIJE I OSNOVNIH VREDNOSTI RIMSKOG PRAVA}

\begin{abstract}
REZIME: Bogata riznica rimskog prava zahteva kontinuirana naučna istraživanja. Vrednosti rimskog prava u procesu globalizacije ostvaruju zapažene rezultate u stvaranju novog ius commune- $a$. Danas se logistički aspekt pravnih sistema Evrope dešava u domenu rimskog prava, a pojedine njegove vrednosti su prepoznatljive pri odvijanju privrednog života na tržištu u okviru susreta nacionalnih prava sa pravom Evropske unije. Metodološki i institucionalizovani okvir prava konkurencije koristi se radi ostvarivanja pozitivnih efekata na jedinstvenom tržištu, trasirajući put ravnomernoj raspodeli društvenog bogatstva. Tržište ne može neutralisati ponašanje poslovnih entiteta koji konkurenciju koriste za ostvarivanje ekstraprofita, pa otkrivanje i stavljanje pod pravni okvir svih mogućih oblika malverzacija kojima se služe poslovni entiteti predstavlja težak zadatak čijom se problematikom bave subjekti politike konkurencije, koristeći se $u$ velikom delu primenom pravnih instituta rimskog prava.
\end{abstract}

Ključne reči: rimsko pravo, pravo konkurencije, bona fides, Jedinstveno tržište Evropske unije

\section{References}

1. Petrušić, N., Adamović, A. (2012). Latinske izreke, pravila i izrazi iz oblasti civilne procedure, [Latin sentences, rules and expressions in the field of civil procedure]. Niš, Centar za publikacije Pravnog fakulteta u Nišu

2. Nikolić, D. (2007). Opšta istorija prava, [General history of law]. Niš, SVEN

3. Miller, W. (1913). M. Tullius Cicero. De Officiis., Cambridge, Harvard University Press, Cambridge, Mass., London, England

4. Stanojević, O. (2003). Rimsko pravo, [Roman Law]. Beograd 
5. Akvinski, T. (1985). Izabrano djelo, [Selected work]. Zagreb

6. Marković-Bajalović, D. (2000). Tržišna moć preduzeća i antimonopolsko pravo, [Company market power and antitrust law]. Beograd, Službeni list SRJ

7. Cini, M., McGowan, L. (2008). Competition Policy in the European Union, 2nd edition, Basingstoke, Palgrave Macmillan

8. Fondation Napoléon (2020, September 15). Code civil des français, [Civil Code of the French]. Downloaded from: https://www.assemblee-nationale.fr/evenements/code-civil-1804-1.asp

9. Judgment of the Court of Justice, in case T-345/12 Akzo Nobel et al. against the Commission, dated 28 January 2015

10. Judgment of the Court of Justice in the case C-453/99, Courage Ltd v. Bernard Crehan and Bernard Crehan v. Courage Ltd et al.

11. Judgment of the ECJ in Joined Cases 56 and 58/64, Consten and Grunding v. EC Commission, 13 July 1966

12. Judgment of the Court (Sixth Chamber) of 3 February 1994, Alfredo Grifoni v European Atomic Energy Community, Non-contractual liability - Compensation for loss, Case C-308/87, ECLI:EU:C:1994:38

13. Judgment of the Court of 27 February 2019, Greece v Commission, European Agricultural Guidance and Guarantee Fund (EAGGF), C-670/17 P, ECLI:EU:C:2019:145

14. Billerud Karlsborg AB v. Swedish Environmental Protection Agency, "Billerud Karlsborg AB v. Naturvardsverket", Case C-203/12 